\title{
CORPORATE SOCIAL RESPONSIBILITY SEBAGAI STRATEGI KOMUNIKASI BISNIS PERUSAHAAN
}

\author{
Marselinus Nuba Sabini dan Leila Mona Ganiem
}

Magister Ilmu Komunikasi Komunikasi Universitas Mercu Buana, Jl. Menteng Raya

No.29 Jakarta Pusat, No Telp (021) 3193-5454

Email: mersi.sabini@gmail.com\&leilamona@gmail.com

\begin{abstract}
This study aims to determine the understanding of the mine repellent group PT.ABC communication strategy through the CSR program. Research using qualitative descriptive approach with the constructivist paradigm. Data collection technique used the techniques of interview and literature study. The study design is done with the design of the case study. The results showed PT.ABC has been running various CSR programs that include four areas of activity: community development, education, health and infrastructure improvements. Nevertheless, the rejection of a repellent group remain. Some of the factors, the program is limited to a certain group, employment is still very limited, and the tendency of corporations to be closed to some sensitive issues like IUP, illegal miners and environmental damage. Constraints faced by the corporation less communicate openly with repellent group, the CSR program is also still limited to a few groups, the limited competence of communicating CSR employee-related mines, as well as the personal interests of the group repellent utilizing the mine issue.
\end{abstract}

Keywords: Communication Strategy, CSR, Public, Group repellent, Mine, Resistance, exploitative.

\section{Abstrak}

Penelitian ini bertujuan untuk menganalisis pemahaman kelompok penolak tambang menggunakan strategi komunikasi melalui program Corporat Social Resposibility (CSR) PT.ABC. Penelitian dilakukan menggunakan pendekatan deskriptif kualitatif. Teknik pengumpulan data menggunakan wawancara dan studi kepustakaan. Desain penelitian dilakukan dengan studi kasus. Hasil penelitian menunjukkan PT.ABC sudah menjalankan program CSR, melalui program pemberdayaan masyarakat, pendidikan, kesehatan, dan perbaikan infrastruktur. Kendati demikian, penolakan masih tetap ada. Beberapa faktor penyebabnya adalah program masih terbatas pada kelompok tertentu, penyerapan tenaga kerja masih terbatas, kecenderungan korporasi untuk tertutup terhadap beberapa isu sensitif, seperti perolehan IUP, penambangan liar dan kerusakan lingkungan. Selain itu, kendala yang dihadapi adalah korporasi kurang berkomunikasi secara terbuka dengan kelompok penolak, program CSR masih terbatas pada beberapa kelompok, keterbatasan kompetensi berkomunikasi karyawan CSR terkait tambang, serta adanya kepentingan pribadi dari kelompok penolak dengan memanfaatkan isu tambang.

Kata kunci: Strategi Komunikasi, CSR, Keterbukaan, Kelompok Penolak, Tambang, Eksploitatif.

\section{Pendahuluan}

Usaha di bidang pertambangan sering mengalami penolakan dari komunitas sekitarnya. Masyarakat sangat reaktif terhadap perusahaan tambang yang berinvestasi di daerahnya. Menurut Prayogo (2004: 47), ada beberapa faktor utama penolakan warga. Pertama, proses pemberian Izin Usaha Pertambangan (IUP) tidak transparan. Sejak diberlakukannya otonomi daerah, IUP menjadi hak Kepala Daerah. Wewenang yang dimiliki sering dimanfaatkan untuk kepentingan politik seperti bantuan biaya untuk Pilkada. Kedua, tidak adanya komunikasi dengan masyarakat di sekitar area pertambangan. Pemerintah daerah dengan para investor tambang hanya melakukan lobi politik di tingkat elit tanpa melibatkan masyarakat. Ketiga, pihak perusahaan mengabaikan hakhak masyarakat lokal. Perusahaan tidak menghargai struktur adat dan sistem sosial masyarakat setempat. Hak ulayat 
warga sering diabaikan dengan alasan sudah mendapatkan IUP. Keempat, perusahaan kurang responsif terhadap kerugian atau penderitaan yang dialami warga, dan terjadinya kesenjangan sosial antara perusahan dengan masyarakat sekitar. Kelima, kerugian lain yang mengikutinya. Dalamlaporan Greenpeace (2014) berjudul "Batubara Melukai Perekonomian Indonesia," diungkapkan bahwa industri ekstraktif batubara diharapkan dapat menjadi penggerak utama perekonomian Indonesia, namun industri ini justru melukai ekonomi nasional, memperburuk kemiskinan, dan mengancam penghidupan masyarakat yang tinggal di sekitar operasi pertambangan batubara.

Industri pertambangan pada dasarnya bermanfaat bagi masyarakat dan pertumbuhan ekonomi nasional, antara lain ; (1)Menciptakan lapangan pekerjaan bagi masyarakat, (2)Hasil produksi tambang dapat digunakan untuk memenuhi permintaan pasar domestik maupun pasar internasional, sehingga hasil ekspor tambang tersebut dapat meningkatkan pendapatan dan pertumbuhan ekonomi negara. Sektor pertambangan juga memberikan efek pengganda yang menjadi pemicu pertumbuhan sektor lainnya serta menyediakan kesempatan kerja bagi sekitar 34 ribu tenaga kerja langsung (http://www.esdm.go.id/).

Tantangan umum yang dihadapi perusahaan tambang saat ini adalah bagaimana mengubah citra tambang yang dipersepsikan sebagai kegiatan yang merusak lingkungan dan merusak tatanan sistem dan soliditas sosial masyarakat. Salah satu cara yang dapat dilakukan perusahaan untuk membangun citra positif adalah menerapkan strategi komunikasi yang tepat dan cocok sesuai dengan karakter lingkungan yang dihadapinya.
Strategi komunikasi adalah suatu transaksi, proses simbolik yang menghendaki orang-orang mengatur lingkungannya (Cangara.2005: 57). Strategi komunikasi perusahaan merupakan hal penting dalam mengelola kondisi lingkungan yang tidak pasti, baik untuk mencegah situasi krisis, maupun ketika perusahaan sedang mengalami situasi krisis.

PT. ABC merupakan salah satu perusahaan yang bergerak di bidang pertambangan tembaga di wilayah Jawa Timur bagian utara. Sejak berdiri pada tahun 2012, PT. ABC sudah menjalankan program Corporate Social Responsibilty (CSR) untuk membangun situasi yang kondusif di lingkungan sekitar. Program Corporate Social Responsibilty (CSR) PT. $\mathrm{ABC}$ dilandasi kesadaran perusahaan untuk berkontribusi positif kepada lingkungan sekitar juga sebagai langkah strategik dalam menghadapi penolakan kelompok penolak tambang.

Pada awal kehadirannya, PT. ABC mendapat penolakan dari mayoritas masyarakat sekitar. Masyarakat penolak memiliki tuntutan. Tuntutan mereka antara lain; (1) Mempertanyakan aspek legalitas perusahaan (IUP), (2) Meminta perusahaan agar berlaku adil dalam perekrutan tenaga kerja dengan mengutamakan masyarakat setempat, (3) Meminta kompensasi uang tunai sebesar 2-3 miliar kepada setiap kepala keluarga (KK), (4)Memberikan lokasi dari IUP untuk masyarakat yang selama ini sudah melakukan penambangan. (5)Meminta perusahaan untuk menjaga moralitas dan menghindari tindakkan asusila di lingkungan sekitar.

Kelompok penolak menggulirkan beberapa isu. Pertama, PT. ABC tidak mampu menerapkan teknik penambangan yang ramah lingkungan. Kedua, isu kesehatan bahwa warga di sekitar tambang akan mengalami 
gangguan kesehatan karena polusi udara dan kebisingan. Ketiga, keberadaan aktivitas pertambangan akan menyebabkan ketidaknyamanan karena lalu lintas alat berat. Keempat, produksi ikan di lautan sekitar lokasi tambang akan berkurang karena pembuangan limbah ke laut. Kelima, penambangan tersebut dianggap dapat mengancam keselamatan masyarakat yang bermukim di sekitarnya karena terpaan angin barat daya pada bulan-bulan tertentu.

Kegiatan komunikasi sosial Departemen CSR PT. ABC dilakukan oleh Divisi Comrel, Govrel, dan Public Relations. Program sosial dari ketiga divisi ini dilaksanakan menurut tingkat kebutuhan masyarakat sekitar sesuai dengan pengkajian dan pengamatan di lapangan. Departemen Corporate Social Responsibilty (CSR) PT. ABC memiliki empat sasaran utama komunikasi sosial yang dilakukan, yaitu; (1)Menjalin komunikasi yang intens dan berkelanjutan dengan unsur pemerintah desa dan Kecamatan, (2) Komunikasiyangintens dan berkelanjutan dengan para kiai dan tokoh agama, (3) Komunikasi dengan masyarakat sekitar area pertambangan terutama di Ring I, (4) Komunikasi dengan kelompok penolak tambang.

Banyak program yang dilakukan CSR PT. ABC untuk membangun citra positif namun penolakan terhadap aktivitas pertambangan tetap ada. Kelompok penolak masih memiliki kecurigaan yang tinggi terhadap perusahaan. Kelompok penolak menilai ada hubungan ekonomi politik antara pengusaha PT. ABC dengan penguasa yang mengakibatkan kerugian ekonomi dan sosial bagi masyarakat lokal. Program CSR PT. ABC tetap dinilai sebagai kegiatan yang lip service untuk membungkam penolakkan warga. Penelitian ini ditujukan untuk menganalisis pemahaman kelompok penolak tambang terhadap strategi komunikasi Departemen Corporate Social Responsibilty (CSR) PT. ABC.

\section{Metode Penelitian}

Penelitian ini menggunakan tipe penelitian deskriptif dengan metode studi kasus. Tipe penelitian deskriptif bertujuan untuk menggambarkan secara sistematis faktual dan akurat mengenai fakta-fakta dan sifat-sifat populasi tertentu (Husaini dan Purnomo, 2006:4). Penelitian deskriptif bersifat pemberian, artinya mencatat secara teliti segala gejala (fenomena) yang dilihat dan didengar serta dibacanya (melalui wawancara, catatan lapangan, foto, video, dokumen pribadi, catatan atau memo, dokumen resmi, tidak sresmi, dan lain-lain. Peneliti membandingkan, mengombinasikan, mengabstraksikan dan menarik kesimpulan (Burhan Bungin. 2007: 93). Teknik pengumpulan data primer dilakukan dengan cara wawancara yang dilakukan secara langsung dan mendalam dengan narasumber penanggungjawab program CSR, Humas PT. ABC, dan masyarakat penolak tambang. Data primer berupa pemahaman masyarakat penolak tambang dan perusahaan PT. ABC mengenai program CSR yang dilakukan, apakah tepat sasaran atau belum. Penelitian ini menggunakan triangulasi sumber untuk memeriksa keabsahan data, yaitu sumber lain dari penolak tambang dan pemerintah .

\section{Hasil Penelitian dan Pembahasan}

Sejak PT. ABC mulai memasuki tahap eksplorasi di Tiwu Tanah Jawa Timur pada 2009, sudah muncul beragam reaksi dari komunitas lokal. Ada kelompok masyarakat yang koperatif, kelompok ini mendukung keberadaan PT. ABC namun dengan beberapa persyaratan, ada yang bersikap netral dan ada juga kelompok yang menolak.

Sejauh ini, sikap penolakan masyarakat sangat dinamis, ada beberapa tokoh 
yang sebelumnya menolak, akhirnya mendukung tambang karena aspirasinya diakomodasi oleh PT. ABC. Banyak masyarakat yang konsisten untuk tetap menolak karena masih menilai bahwa PT. ABC belum memberi banyak manfaat untuk warga sekitar tambang.

Kelompok penolak tambang PT. $\mathrm{ABC}$ adalah warga yang bekerja sebagai petani, penambang rakyat, orang yang berkepentingan dengan isu tambang, dan aktivis lingkungan. Para penolak mengharapkan resistensi terhadap aktivitas pertambangan menjadi gerakan bersama dari semua kelompok yang merasa dirugikan.

Bentuk penolakan antara lain; (1) Demonstrasi di lokasi tambang, (2) Menyebarkan opini negatif kepada komunitas sekitar,(3) Pemasangan spanduk dan menyebarkan selebaran penolakan di jalan dan tempat umum, (4) Menuntut ke bupati dan lobi di DPRD kabupaten untuk mencabut IUP PT. ABC.

Tuntutan dibuat oleh kelompok penolak dan mengarah pada beberapa isu, yaitu ; (1) Mempertanyakan aspek legalitas perusahan (IUP). Menurut mereka, IUP yang diberikan oleh bupati tidak melalui prosedur yang jelas dan transparan. Bupati memberikan IUP dari perusahaan ITC ke PT. ABC tanpa melalui sosialisasi kepada masyarakat di sekitar Tiwu Tanah, (2) Perekrutan karyawan dari warg a lokal terutama di Ring I tidak sesuai harapan komunitas. Menurut penolak tambang, perekrutan tenaga kerja belum mampu menyerap tenaga kerja, masih banyak anak muda di Ring I yang menganggur. Perekrutan warga lokal juga masih terbatas pada tenaga non-skill, (3) Meminta ganti rugi uang tunai sebesar 2-3 miliar per-Kepala Keluarga. (4) Memberikan area penambangan untuk penambang tradisional yang selama ini sudah melakukan penambangan, termasuk di area IUP PT. ABC, (5) Menuntut perusahaan agar peduli dan respect dengan warga sekitar, menghindari tindakan asusila dan mencegah kesenjangan sosial antar karyawan dengan warga sekitar.

Dalam penelitian ini ditemukan bahwa terdapat ketidakseimbangan relasi yang terjadi antara PT. ABC dengan kelompok penolak tambang. Dalam hubungan sosial, ada pola komunikasi yang dominan dari pihak perusahaan yang menentukan pola hubungan sosial, ekonomi dengan komunitas sekitar. Ketidakseimbangan hubungan tersebut berpengaruh pada cara pandang terhadap satu sama lain.

Kontras dengan itu, masyarakat setempat dan penambang tradisional tidak memilikimodalyangcukupuntukmengelola kekayaan alam di lingkungannya. Mereka hanya mengandalkan peralatan tradisional dengan fasilitas seadanya, dengan teknik penambangan yang sederhana, juga tidak memiliki rencana penambangan jangka panjang. Komunitas sekitar dan penambang liar yang kurang berpendidikan, dan tidak memiliki keahlian dalam bidang pertambangan. Mereka juga tidak dapat direkrut menjadi karyawan yang ber-skill karena kurang terlatih. Sehingga mereka hanya berharap untuk direkrut menjadi karyawan non-skill dan mendapatkan keuntungan ekonomis dari penambangan. Sementara keberadaan penambang liar di sekitar daerah penambangan PT. ABC tidak mendapat izin resmi dari pemerintah daerah. Petak yang selama ini menjadi lahan penambangan warga merupakan bagian dari wilayah IUP PT. ABC. Dengan ketiadaan perlindungan politik dan hukum, aktivitas penambangan liar tersebut kapan saja dapat dihentikan oleh pemerintah.

\section{Strategi Komunikasi PT. ABC}

Strategi komunikasi PT. ABC adalah bentuk respon dari perusahaan terhadap tuntutan warga. Tujuan penolakan dari warga adalah untuk mendapatkan respon dari perusahaan. Oleh karena itu, strategi komunikasi harus memahami kebutuhan 
warga dan kondisi sosial ekonomi yang berkembang di komunitas dengan cara ; (1) Merekrut karyawan non skill dari masyarakat setempat. Dalam perekrutan tenaga kerja terutama yang non skill, PT. ABC memprioritaskan masyarakat lokal di Kecamatan Seredindung yang tersebar dilimadesa.Padasaatinijumlahkaryawan yang berkerja di PT. ABC 797 orang. Dari jumlah tersebut yang berasal dari warga lokal berjumlah 762 orang, dan ada 573 orang yang berasal dari wilayah Ring I, Kecamatan Seredindung, (2)Memberi perhatian khusus kepada tokoh penolak. Departemen Corporate Social Responsibilty (CSR) PT. ABC memberi perhatian kepada para tokoh penolak dengan berbagai bentuk bantuan dan kerja sama yang saling menguntungkan. Setiap program sosial Corporate Social Responsibilty (CSR) selalu dikomunikasikan dengan mereka, masukan para tokoh menjadi materi pertimbangan dalam perumusan kebijakkan dan distribusi program, (3) PT. ABC bekerja sama dengan kelompok penolak dengan menjadikan mereka local supplier. PT. ABC berkomitmen untuk memberdayakan masyarakat lokal dengan menjadikan mereka sebagai suplier beberapa jenis materil bangunan dan makanan. PT. ABC juga menyewajasa kendaraan para pengusaha lokal. Selain itu, perumahan warga dijadikan kantor dan camp sejak tahap eksplorasi hingga tahap konstruksi. Dari 102 mitra kerja,84 diantaranya berasal dari Kecamatan Seredindung. Pembelian kepada mitra kerja lokal selama bulan Januari-Juni 2015 terus meningkat dengan nilai keseluruhan mencapai Rp 4,378 Milyar.

Manajemen PT. ABC merespon tuntutan dengan mengalokasi waktu staf Corporate Social Responsibilty (CSR) untuk lebih banyak berada di lapangan agar dapat membaur dengan masyarakat. Tujuannya, untuk menemui dan menjalin silaturahmi dengan kelompok penolak atau masyarakat yang belum bersikap terbuka terhadap perusahaan karena tidak mendapat informasi yang memadai terkait PT. ABC. Dalam setiap perjumpaan dengan warga, staf Corporate Social Responsibilty (CSR) memberikan penjelasan terkait tambang, kegiatan sosial yang sudah dilakukan PT. ABC, dan sisi manfaat tambang.

Departemen Corporate Social Responsibilty (CSR) PT. ABC merekrut karyawan perempuan yang memiliki kompentensi komunikasi yang bagus dan pemahaman terhadap dunia pertambangan. Ini merupakan bentuk strategi perusahan untuk menarik simpati warga yang cenderung bersikap keras terhadap perusahaan. Para karyawati itu melakukan pendekatan komunikasi interpersonal yang asertif dan persuasif dengan tokoh penolak dan warga. Mereka mensosialisasikan program CSR perusahaan, manfaat tambang dan menjawab berbagai pertanyaan masyarakat terkait tambang.

Pengembangan kegiatan pemberdayaan masyarakat bertujuan untuk meningkatkan kemandirian masyarakat lokal dalam memanfaatkan potensi kekayaan alam di lingkungannya. Pemberdayaan masyarakat lokal menjadi sangat penting karena mereka tidak memilikimodalyangcukup, keterampilan yang terbatas dan tidak memiliki kekuatan politik-hukum berhadapan dengan perusahaan. PT. ABC telah melakukan program pemberdayaan, yaitu; (1) Membantu pengembangan usaha pertanian, perikanan dan peternakan, (2) PT. ABC memberdayakan kaum ibu melalui pembudidayaan tanaman sayuran dan lainnya, (3) PT. $\mathrm{ABC}$ membangun kerja sama dengan para pengusaha lokal agar mampu bersaing dengan pengusaha dari daerah lainnya. Mereka menjadi local supplier kebutuhan operasional perusahan dan penyedia jasa 
penyewaan transportasi dan perumahan.

Program Corporate Social Responsibilty (CSR) juga ditujukan untuk perbaikan dan penyediaan infrastruktur di lingkungan sekitar area tambang. Program-program itu meliputi proyek saluran irigasi, gedung Taman Pengajian, bedah rumah warga dan pembangunan jogging track lapangan olah raga.

Perbaikkan sarana infrastruktur juga dilakukan dalam bidang pendidikan. Antara lain, perbaikan gedung sekolah, penyediaan perpustakaan dan penambahan ruang kelas di Kecamatan Seredindung. Program di bidang kesehatan yang sudah dijalankan antara lain, program Bakti Sosial Kesehatan, Pengobatan Gratis.

Komunikasi dengan tokoh masyarakat dilakukan staf Corporate Social Responsibilty (CSR) dengan menerapkan model komunikasi interpersonal dengan para tokoh, baik tokoh adat maupun tokoh agama.

Model komunikasi interpersonal PT. ABC menjelaskan kegiatan yang dilakukan karyawan dalam melakukan
Corporate Social Responsibility (CSR) dengan mengunjungi rumah para tokoh untuk berdiskusi dan melakukan sosialisasi program perusahaan. Dalam beberapa kesempatan, para tokoh diundang ke camp pertambangan untuk silahturahmi. Diharapkan dengan kegiatan tersebut terbangun opini yang positif kepada perusahan. Kedua, dilakukan komunikasi dengan kelompok penolak tambang. Staf Corporate Social Responsibility (CSR) secara intens bertemu dengan kelompok penolak tambang untuk beramah tamah sehingga pihak perusahaan tahu apa yang menjadi keinginan mereka. Ketiga, media gathering. Peranan media massa sangat penting dalam menyampaikan informasi yang benar dan objektif kepada masyarakat, oleh karena itu diperlukan media agar bisa menyampaikan informasi mengenai apa yang telah dilakukan oleh PT. ABC dalam memenuhi tuntutan masyarakat.

Seperti yang terjadi di daerah lainnya, penolakan warga terhadap tambang didasari sikap kecurigaan atau prasangka terhadap perusahaan karena merasa keuntungan ekonomis dari hasil

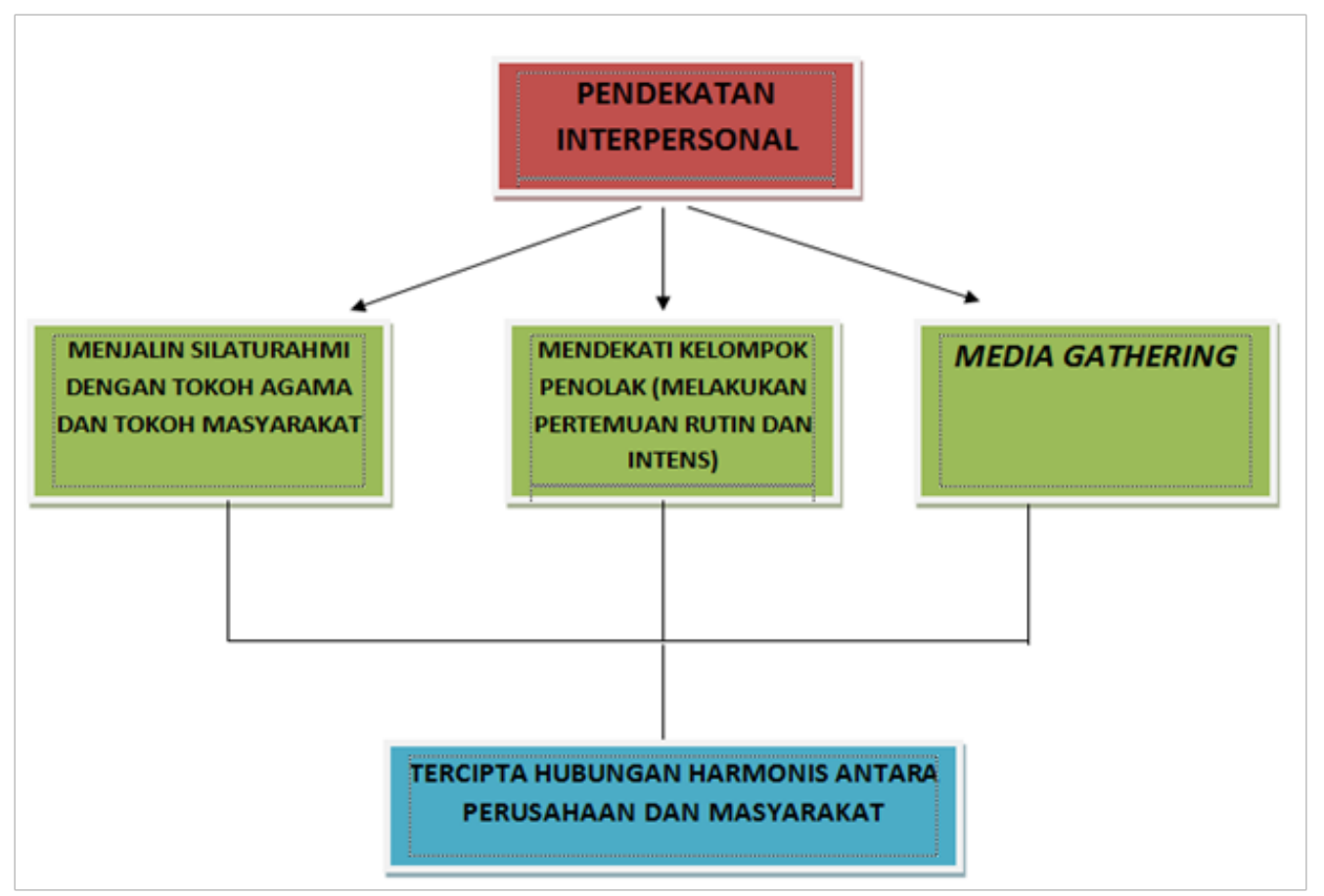

Gambar 1. Model Komunikasi Interpersonal PT. ABC 
sumber daya alam di lingkungan mereka tidak memiliki trickle-down effect kepada masyarakat. Dalam rentang waktu 3 tahun terakhir, kelompok penolak tambang yang terdiri LSM dan beberapa tokoh masyarakat setempat terus melakukan aksi penolakan terhadap perusahaan. Disisi lain hal positif datang dari kerja sama antara pemerintah kecamatan, desa dengan PT. ABC. Hal ini tercermin dari adanya beberapa kebijakan dan program pemerintah yang merupakan hasil rumusan bersama dengan pihak PT. ABC.

Penolakan tambang karena adanya program Corporate Social Responcibility (CSR) hanya dinikmati segelintir orang. Keuntungan PT. ABC tidak ada untuk warga setempat. Beberapa Lembaga Swadaya Masyarakat (LSM) yang ada di sekitar perusahaan menyayangkan sikap perusahaan yang dinilainya tidak adil dalam merekrut tenaga kerja. Bagi Lembaga Swadaya Masyarakat (LSM), perusahaan gagal menekan angka pengangguran di wilayah tersebut.

Keuntungan yang didapat oleh PT. ABC sangat besar sementara yang diterima masyarakat hanya sebagian kecil saja. Kami melakukan demonstrasi atas dasar tersebut. LSM dan warga penolak lainnya menuntut agar mendapat uang kompensasi per-kepala keluarga dipandang layak. Pihak yang dirugikan atas berdirinya perusahaan perusak lingkungan, tidak mendapat kerugian yang kedua kalinya, (wawancara dengan Rosid, salah satu anggota dari Lembaga Swadaya Masyarakat (LSM)).

Salah seorang warga setempat mengatakan bahwa program CSR PT. ABC terlalu monoton kepada orang kelompok penolak tambang, sehingga kelihatannya program CSR hanya untuk membujuk para tokoh agar mengubah sikap dan berpihak pada perusahaan.

Berdasarkan pengamatan di lapangan dan wawancara dengan para tokoh penolak, peneliti menilai bahwa isu penolakan tambang dari kelompok penolak tidak berdiri sendiri dengan isu lainnya. Isu tambang dijadikan medium untuk mendapatkan dan memperjuangkan sesuatu yang lain dari kelompok penolak. Artinya, kelompok penolak tambang memiliki misi pribadi terkait isu tambang, tidak murni untuk memperjuangkan warga.

Kerusakan lingkungan menjadi salah satu isu yang berkembang saat ini. Gugusan di wilayah tersebut berfungsi untuk menghadang terpaan angin pada bulan tertentu. Masyarakat mencemaskan apabila nanti pegunungan Tiwu Tanahdigusur, maka akan membahayakan keselamatan mereka terutama bagi yang berada di sekitar lokasi tambang.

Illegal mining merupakan salah satu isu penting terkait pengelolahan aset Tiwu Tanah. Para penambang tradisional berjumlah sekitar 1000 orang. Dengan dimulainya eksplorasi PT. ABC sangat potensial untuk menghentikan aktivitas para penambang liar. Padahal, penambangan rakyat yang sudah mereka lakukan selama ini sudah menjadi pekerjaan pokok.

Penolakan terhadap tambang Tiwu Tanah tidak terlepas dari kepentingan politik. Pada pemilu legislative tahun 2014 lalu, banyak caleg yang menggunakan isu tambang untuk menggalang dukungan warga. Para caleg berjanji akan berjuang untuk menghentikan aktivitas tambang di Tiwu Tanah apabila terpilih. Pada saat itu, isu tambang kembali menghangat dan mendapat dukungan penuh dari kelompok penolak.

Kelompok penolak tambang memiliki misi pribadi dalam memainkan isu tambang. Antara lain dari sisi sosial mereka mau diakui sebagai tokoh yang memperjuangkan nasib warga sekitar. Dari sisi ekonomi, kelompok penolak 
sebenarnya mendapatkan perhatian khusus dari PT. ABC dengan menjadikan mereka local supllier bahan makanan, materil bangunan dan berbagai bentuk kerja sama lainnya. Mereka memainkan isu tambang dengan tujuan agar perusahan memberikan respon dengan melakukan pendekatan pribadi kepada kelompok penolak.

Penolakan merupakan sebuah fenomena sosial dari pihak yang dirugikan oleh kelompok dominan yang mendominasi aset strategis di lingkungan sekitarnya. Sikap ini sebagai konsekuensi dari relasi yang tidak seimbang antara perusahan yang didukung oleh kekuatan politik-hukum dari pemerintah daerah dengan komunitas sekitar yang tidak mampu mengimbangi dominasi tersebut. Sebagaimana yang dikatakan oleh Gallie dan Paugam dalam Silver (2007: 12), bahwa eksklusi sosial merujuk pada suatu situasi di mana orang-orang menderita sebagai akibat dari ketidak-beruntungan secara kumulatif dari marjinalisasi di pasar kerja, kemiskinan, dan isolasi sosial. Aspek yang saling terkait ini yang menyebabkan individu tidak memiliki sumber daya ekonomi dan sosial untuk berpartisipasi di kehidupan sosial.

James Scott, (2000: 321), mendefinisikan resistensi atau penolakan sebagai semua tindakan dari anggota masyarakat kelas bawah dengan maksud untuk mempertahankan kelangsungan hidupnya. Setiap tindakan anggota kelas masyarakat yang rendah dengan maksud melunakkan atau menolak tuntutan-tuntutan yang dikenakan pada kelas itu oleh kelas-kelas yang lebih atas (misalnya tuan tanah, negara, pemilik mesin, pemberi pinjaman uang) atau untuk mengajukan tuntutan-tuntutannya sendiri (misalnya pekerjaan, lahan, kemurahan hati, penghargaan) terhadap kelas-kelas atas.

Penolakan dalam konsep James Scott bertujuan untuk mendapatkan reaksi dari pihak yang dilawan. Penolakan dapat dilihat sebagai upaya untuk membangun keseimbangan dan kesetaraan dari situasi yang menghimpit kelompok lemah akibat tindakan atau kebijakkan kelompok yang lebih kuat. Sehingga pada hakikatnya, resistensi muncul sebagai usaha untuk mencapai demokrasi yang secara nyata memberikan kebebasan dan kesetaraan (Hardt \& Negri. 2000: 223).

Dalam banyak kasus, penyebab konflik pertambangan di Indonesia adalah faktor politik, hukum, sosial dan ekonomi. Pertama, penguasaan lahan tanah ulayat oleh perusahaan tambang dengan payung IUP oleh Pemda. Sepanjang 2013, KPA mencatat 369 konflik agraria dimana kasus pertambangan sebesar $38(10,3 \%)$. Kondisi ini sejalan dengan teori kelangkaan yang dikemukakan oleh Michael Harner (1970), Morton Fried (1967) dan Lesser Blumberg (1978) dalam (Ansori. 2013: 69), bahwa tekanan penduduk dan kelangkaan lahan untuk produksi akan menyebabkan konflik, karena tekanan penduduk menyebabkan perbedaan akses terhadap sumber daya ekonomi. Konflik penguasaan lahan ini disebabkan oleh tidak adanya pengakuan kuat tentang hak-hak masyarakat adat terhadap tanah, wilayah dan sumber daya pertambangan.

Pada dasarnya strategi komunikasi adalah penentuan pendekatan yang digunakan oleh suatu perusahaan atau organisasi terhadap harapan komunitas sekitar dan bagaimana melaksanakan pendekatan tersebut dengan memanfaatkan sumber daya yang ada sesuai dengan kondisi lingkungannya. Dengan terciptanya dominasi PT. ABC atas komunitas lokal, PT. ABC perlu menerapkan strategi komunikasi agar kesenjangan itu tidak berlangsung terus menerus dan mengakibatkan konflik sosial, namun mengharapkan terjadinya 
perubahan persepsi terhadap PT. ABC sehingga terbangunnya kerja sama yang baik atas dasar saling pengertian dan menguntungkan.

Ketika sebuah organisasi berpikir tentang strategi, dapat diartikan bahwa organisasi tersebut mempunyai visi masa depan, membangun kekuatan dan melakukan pendekatan-pendekatan yang berorientasi pada tujuan dan aksi. Untuk itu organisasi akan menentukan skala prioritas, dan mengelola aktivitas, anggaran dan sumberdaya manusianya secara sistematis, agar tujuan organisasi tercapai.

Kesepahaman antara kedua pihak pada hakikatnya dapat terwujud bila kedua kelompok saling membuka diri untuk berdialog dan komunikasi. Kalau terbangun kesamaan persepsi dan kesepahaman maka akan menentukan sikap dari satu kelompok terhadap kelompok lainnya. Pihak korporasi sebagai pendatang seharusnya melakukan komunikasi yang terbuka dan berkelanjutan kepada masyarakat sekitar baik yang pro dengan korporasi maupun yang kontra. Komunikasi korporasi dilandasi suatu keyakinan bahwa masyarakat pada dasarnya bersifat terbuka dan ingin berdialog secara terbuka baik dengan perusahan maupun dengan pemerintah. Prinsip kesetaraan dan keadilan harus menjadi landasan bersama agar tercipta hubungan yang seimbang, tidak ada kelompok yang bertindak dominan.

Lingkungan sekitar harus merasakan adanya niat baik dari perusahan untuk saling menghormati dan saling mendengar satu sama lain. Program-program Corporate Social responsibility (CSR) sebagai strategi komunikasi perusahaan harus diterapkan dalam kerangka kerja sama yang saling mendukung dan berbagi agar semuanya mendapatkan manfaat tidak hanya untuk jangka menengah tetapi juga untuk jangka panjang. Dengan demikian, korporasi dapat menjauhkan diri dari kecendrungan untuk mendominasi lingkungan sekitar.

Komunikasi merupakan hal yang sangat penting bagi suatu perusahaan dalam mengelolah lingkungan yang tidak pasti. Tantangan dunia usaha pertambangan dari waktu ke waktu semakin besar dan sering terjadi tanpa dapat diprediksi sebelumnya. Bagi perusahaan yang tidak memiliki kemampuan manajemen komunikasi strategik akan mengalami kesulitan untuk menentukan solusi terbaik untuk mengelola situasi kritis tersebut.

Dalam banyak kasus, masalah sosial terjadi karena perusahaan sering mengabaikan komunikasi perusahaan dengan lingkungan sekitar. Kecendrungan umum yang terjadi adalah korporasi kurang terbuka dan tidak transparan dengan masyarakat. Padahal, komunikasi yang terbuka merupakan langkah awal untuk membangun kesepahaman dan rasa saling percaya. Dengan komunikasi perusahaan akan didapat dengan langsung apa yang menjadi harapan, keluhan dan masukan dari komunitas dan masyarakat sekitar.

Implikasi hasil studi ini menjelaskan bahwa program Corporate Social responsibility (CSR) merupakan salah satu pilihan alternatif bagi perusahaan tambang dalam menghadapi lingkungan yang tidak pasti, terutama penolakan warga sekitar tambang. Program Corporate Social responsibility (CSR) merupakan bentuk strategi komunikasi perusahaan yang berakar pada adanya kesadaran dari pihak manajemen perusahan bahwa lingkungan yang kondusif dapat tercipta melalui kerelaan korporasi untuk melibatkan diri dan berbuat sesuatu bagi masyarakat lokal. Setiap perusahaan membutuhkan strategi komunikasi yang baik agar bisa mencapai tujuannya.

\section{Simpulan}

Komunikasi yang dilakukan oleh PT. ABC pada tahap awal operasi dan proses pengalihan IUP dari perusahaan 
sebelumnya ke PT. ABC kurang melibatkan masyarakat luas terutama kelompok aktivis dan tokoh yang berkepentingan dengan Tiwu Tanah. Masyarakat kurang memahami program PT ABC karena belum diberi penjelasan secara utuh terkait dengan penambangan seperti teknik penambangan, pengelolahan limbah, dan pengelolahan lingkungan.

PT. ABC menyadari perlunya kontribusi positif bagi komunitas lokal, sesuai dengan misinya yaitu ikut meningkatkan kesejahteraan masyarakat sekitar melalui pelaksanaan programprogram Corporate Social responsibility (CSR) yang terdiri dari 4 pilar (pendidikan, kesehatan, pemberdayaan ekonomi dan infrastruktur).

Kelompok penolak tambang memiliki motivasi pribadi atau bersikap ganda dalam perjuangan menolak keberadaan tambang di Tiwu Tanah. Hal ini dibuktikan dengan karakteristik penolak tambang: (a)Penolak tambang tetapi mau menjalin kerja sama dengan PT. ABC sebagai local suplier, misalnya menjadi penyedia gorong-gorong, batu bata dan bahan makanan, (b) Penolak tambang mengajukan proposal permohonan bantuan kepada perusahaan dengan jumlah besar, (c)Kelompok penolak tambang mengharapkan kompromi dan dialog dengan PT. ABC dalam memperjuangkan kepentingannya baik untuk keuntungan ekonomi maupun pengakuan sosial.

Isu penolakan terhadap tambang di Tiwu Tanah tidak murni berjuang untuk kepentingan pihak yang dirugikan namun berhubungan dengan kepentingan politik. Terbukti, isu tambang semakin kuat pada masa menjelang pilkada, pileg dan pilkades. Pada pemilu 2014, banyak caleg asal Seredindung menjadikan isu tambang Tiwu Tanah sebagai jualan politik.

Implikasi penelitian ini bahwa PT.
ABC harus meningkatkan kegiatan Program Corporate Social responsibility (CSR) yang melibatkan banyak orang seperti olahraga bersama dan kegiatan yang sifatnya mengumpulkan massa dalam jumlah besar, seperti olahraga bersama, rekreasi bersama warga dan megambil prakarsa dalam acara besar seperti acara agustusan. Program pemberdayaan perlu diperluas lagi dan meningkatkan pendampingan yang lebih solid, sehingga memudahkan kontrol dan pencapaian target baik jangka pendek maupun jangka panjang. PT. ABC perlu menjembatani dominasi perusahan atas warga lokal dengan membina hubungan sosial yang lebih solid untuk mengurangi kesenjangan sosial. Pelaksanaan program Corporate Social responsibility (CSR) PT. $\mathrm{ABC}$ perlu didukung oleh kemampuan komunikasi yang partisipatif, edukatif, dengan berprinsip pada kesetaraan, kebersamaan dan saling berlajar. PT. ABC meningkatkan kapasitas dan kompetensi komunikasi para karyawan Program Corporate Social responsibility (CSR) untuk merespon aspirasi masyarakat dan menjelaskan hal-hal teknis berkaitan dengan pertambangan.

Bagi perusahan tambang di tempat lain agar membangun komunikasi terbuka dan sosialisasi terutama terkait perizinan dan aspek teknik sampai ke level masyarakat sejak awal kegiatan penambangan. Sosialisasi yang baik dari awal memudahkan langkah perusahan dalam tahapan proses penambangan selanjutnya. Keterbukaan dengan masyarakat merupakan hal yang sangat penting untuk meminimalisir penolakan warga karena kurangnya pemahaman terhadap profil dan kegiatan perusahaan. Korporasi tidak boleh mengabaikan atau membiarkan terjadinya situasi sosial yang kurang kondusif walaupun itu masih dalam skala kecil, karena konflik sosial bermula dari hal-hal kecil yang 
selanjutnya bergerak secara terpola yang pada akhirnya menjadi konflik sosial.

\section{Daftar Pustaka}

Ansori, Mohammad Hasan. 2013. Desentralisasi Korupsi, dan Kemunculan IUP di Indonesia. Jurnal Demokrasi dan HAM Vol. 10, 2013 The Habibie Center.Jakarta: UNJ.

Cangara, H. 2005. Pengantar Ilmu Komunikasi. Jakarta: PT. Raja Grafindo Persada

Hardt, Michael dan A. Negri. 2000. Biopolitical Production dalam Empire. Cambridge: Harvard University Press.

Husaini Usman dan Purnomo Setiadi Akbar. 2006. Metodologi Penelitan Sosial, Jakarta: Bumi Aksara.
Prayogo, D.2004. Konflik Antara Korporasi dan Komunitas: Pengalaman Beberapa Industri. Tambang dan Minyak di Indonesia. Jurnal Masyarakat No 13. Jakarta: Fisip UI.

http://www.greenpeace.org/seasia/ id / press / releases / LaporanGreenpeace-Selain-MerusakLingkungan-Industri-BatubaraMelukai-Perekonomian-Indonesia/

Scott, James. 2000. “ Weapons of The Weak; Everyday Forms of Peasant Resistance. Chicago: Yale University Press.

Tambang dan Minyak di Indonesia. Jurnal Masyarakat No 13. Jakarta: Fisip UI. 